\title{
RECENZJE
}

\section{Mateusz Wyżga, Urzędnicy miejscy Bochni do 1772 roku, Spisy urzędnikóu miejskich z obszaru dawnej Rzeczpospolitej, Śląska i Pomorza Zachodniego, t. 3: Małopolska, z. 4 Bochnia, Toruń 2018, ss. 242}

Drzedmiotem recenzji jest wydana niedawno na rynek publikacja będąca 1 kontynuacją serii realizowanej za pomocą grantu finansowanego przez Narodowy Program Rozwoju Humanistyki. Książka ta jest nieformalnie rozbita na dwie części, to znaczy nie została przez autora podzielona na rozdziały, żadnemu fragmentowi tekstu nie został przypisany numer porządkowy, co powoduje trudność w „poruszaniu się” po niej. Spis obejmuje:

Wstęp

Organy komunalne i urzędy miasta Bochni

- Rada miejska

- Ława sądowa

- Wójtostwo

- Communitas i organ dwunastu mężów

- Inne urzędy i służby komunalne

- Uwagi do spisów 
Rajcy

Ławnicy

Wójtowie dziedziczni, zarządcy i dzierżawcy wójtostwa, starostowie bocheńscy

Pisarze miejscy

Indeksy

Pierwsza ze wspomnianych wyżej części to tekst w postaci informacji o radzie miejskiej, ławie sądowej, wójtostwie, communitas i organie 12 mężów oraz innych urzędach i służbie komunalnej), druga zaś obejmuje spisy. W pracy zawarto także wstęp oraz indeks osobowy, zabrakło jednak zakończenia i wykazu cytowanych publikacji, tak zwanej bibliografii załącznikowej. Szata graficzna nawiązuje do reszty publikacji z serii.

$\mathrm{Na}$ kilku kartach wstępnych przedstawiono założenie pracy, to znaczy kontynuacje w ramach ${ }^{1}$. Omówiono literaturę przedmiotu, wykorzystaną podstawę źródłową oraz historię miasta Bochni, począwszy od lokacji aż do 1772 roku, czyli momentu kiedy to miasto w wyniku zaboru dostało się pod panowanie Austrii. Już we wstępie należy zauważyć, że poszczególne jego fragmenty mają nieprzejrzysty układ. Ogromną zaletą pracy jest wykorzystanie szerokiego spektrum źródeł. Jednakże wykorzystane materiały archiwalne, które powinny być opisane tuż przed lub ewentualnie tuż po przedstawieniu literatury, a nie jak to uczynił autor, po rysie historycz$n^{2}{ }^{2}$. Również nie do przyjęcia jest fakt, iż autor nie podał w przypisie adresów bibliograficznych do pozostałych tomów w serii, chociaż wskazuje ich istnienie ${ }^{3}$. Pewnym mankamentem są także $\mathrm{w}$ moim odczuciu pewne potknięcia, jeżeli chodzi o sposób „ubierania w słowa” pewnych rzeczy. Mianowicie w tym miejscu należy wyliczyć stosowanie określenia „przedsiębiorstwo” w odniesieniu do pracy w kopalni soli, podczas gdy jest

${ }^{1}$ Z. Noga, Urzędnicy miejscy Krakowa. Cz. 2, 1500-1794: Spisy urzędników miejskich z obszaru dawnej Rzeczpospolitej, Ślaska i Pomorza Zachodniego, t. 3: Małopolska, z. 1 Kraków, Kraków 2008.

2 M. Wyżga, Urzędnicy miejscy Bochni do 1772 roku, Spisy urzędników miejskich z obszaru dawnej Rzeczpospolitej, Ślaska i Pomorza Zachodniego, t. 3: Małopolska, z. 4 Bochnia, Torun 2018, s. 13-14, 16-17.

3 Ibidem, s. 5. 
to anachronizm w czystej postaci ${ }^{4}$. Błędem jest także stosowanie określenia „szlachta pochodzenia mieszczańskiego”, która zdaniem autora nie podlegała prawu miejskiemu. Otóż ktoś kto mieszkał w mieście i przyjmował prawo miejskie, temuż prawu podlegał, przez co stawał się mieszczaninem ${ }^{5}$. Poza tym szlachta chcąc mieszkać w mieście podlegała prawu miejskiemu, po prostu się do niego nie stosowała, co mogło owocować licznymi konfliktami. $\mathrm{Na}$ dalszych kartach tego wstępu można zauważyć drobne niedociaggnięcia rzutujące jednak na jakość pracy. Przykładem jest porównywanie Bochni do innych miast jej wielkości, nie przytaczając jej wielkości, a jedynie dając przypis do literatury ${ }^{6}$. Zwykle przy tej okazji cytowana jest czterostopniowa skala zaproponowana przez Marię Bogucką i Henryka Samsonowicza ${ }^{7}$. Nieco niezrozumiałe zdają się zdania odnoszące do rosnącego analfabetyzmu w mieście w kontekście jego upadku. Zupełnie zbędne wydaje się zdanie mówiące o tym, że Bochnia „dzieliła dole i niedole państwa polskiego"'. Należy zadać sobie pytanie, czy inne miasta tego nie dzieliły? Ponadto należałoby unikać uogólnień budowanych na podstawie jednej, czy dwóch wzmianek. Odnosi się to do stwierdzenia, iż „nie wszyscy bocheńscy oficjaliści żupni chcieli obarczania ich dodatkowymi funkcjami w urzędzie" ${ }^{10}$. Piastowanie godności miejskich zawsze wiązało się z dodatkowymi przywilejami bądź zarobkami, które autor sam przytoczył, więc dlaczego mieszczanie bocheńscy mieliby z tego nie skorzystać? ${ }^{11}$. Niezbyt trafne jest upatrywanie w ratuszu „symbolu rangi władzy królewskiej” ${ }^{12}$. Czy idąc tym tropem ratusz w mieście szlacheckim będzie symbolem władzy szlachcica? Kontrowersyjna jest również posta-

${ }^{4}$ Ibidem, s. 7, 10 .

5 Ibidem, s. 10.

6 Ibidem, s. 12.

${ }^{7}$ M. Bogucka, H Samsonowicz., Dzieje miast i mieszczaństwa $w$ Polsce przedrozbiorowej, Wrocław, Warszawa, Kraków, Gdańsk, Łódź: Zakład Narodowy im. Ossolińskich, 1986, s. 117.

8 Ibidem, s. 12.

9 Ibidem, s. 13.

10 Ibidem, s. 11.

${ }^{11}$ Ibidem, s. 28-29.

12 Ibidem, s. 13. 
wiona przez autora cezura końcowa wyznaczona datą 1772 rok $^{13}$. Owszem, oznaczało to koniec funkcjonowania miasta w Rzeczpospolitej, lecz nie oznaczało kresu funkcjonowania jako organizm miejski w ogóle. Wpisy w księdze radzieckiej Bochni wpisywano co najmniej do 1786 roku, świadczy o tym zachowana księga radziecka ${ }^{14}$. Z dużym prawdopodobieństwem można by rzec, że okres „księgi wpisów” w Bochni musiał trwać jeszcze do pierwszej połowy XIX wieku. Po tym czasie w wielu kancelariach miejskich zaczynano stosować system akt spraw.

W kolejnych dwóch „rozdziałach” opisano organizacje, wybór, uroczystość zaprzysiężenia oraz kompetencje rady miejskiej i ławy sądowej, które są bardzo mocnym elementem tych rozważań ze względu na dużą szczegółowość w tym zakresie. W tej materii widać sporą różnicę w porównaniu do miast szlacheckich. Jedyną cechą wspólną łączące te urzędy w obu typach miast są kompetencje, które w zasadzie były zbliżone. Zostając jeszcze przy temacie obu urzędów należy powiedzieć, że skromnie (lecz raczej śladowo) opisano cursus honorum - kariery urzędników miejskich Bochni oraz familie urzędnicze ${ }^{15}$. Innymi słowy nie udało się autorowi dokonać pełnego ujawnienia karier urzędniczych Bochni, do czego miały przyczynić się spisy. W tym miejscu autor pozwolił sobie na kolejne duże uogólnienie uważając, że „typowa ścieżka kariery urzędniczej w Bochni, podobnie jak w innych miastach polskich prawa magdeburskiego wiodła $z$ urzędu ławniczego, do rady urzędującej, a następnie do rady starej" ${ }^{16}$. Osobiście przebadałem blisko 40 szlacheckich ośrodków miejskich Wielkopolski lokowanych na prawie magdeburskim i nie spotkałem się jak dotąd z tym, aby w choć jednym z nich istniała rada stara. Poza tym kariera urzędnicza mogła brać swój początek od urzędu pisarza, jak chociażby $\mathrm{w}$ Inowrocławiu, lokowanym również na prawie magdeburskim ${ }^{17}$. Nieprzemyślana wydaje się opinia autora, iż pełna postać samorządu miejskiego wytworzyła się tuż po lokacji (1253), skoro

13 Ibidem, s. 15.

${ }^{14}$ Archiwum Narodowe w Krakowie, Akta miasta Bochni, sygn. I 66.

${ }^{15}$ M. Wyżga, op. cit., s. 27-28.

16 Ibidem, s. 27.

17 W. Chorążyczewski, Ustrój Inowroctawia w XVI - XVIII wieku i urzędnicy miejscy, „Ziemia Kujawska” 2015, t. 14, s. 72. 
zachowane księgi rady pochodzą dopiero z pierwszej połowy XVI wieku ${ }^{18}$. $\mathrm{Z}$ literatury wiadomo, iż rada miejska pojawiała się wraz z lokacją tylko w miastach lokowanych na prawie lubeckim, w pozostałych przypadkach (nawet dużych miast), było to rozciagnnięte w czasie ${ }^{19}$. Potwierdzenie tej kwestii dla Bochni wymagałoby jednak przeprowadzenia analogicznego badania. Aczkolwiek mając w pamięci fakt, iż Bochnia została lokowana na prawie niemieckim w odmianie pochodzącej z Magdeburga, należy więc wykluczyć tak szybkie wytworzenie się pełnego samorządu. Późno też zdarzył się wykup wójtostwa dziedzicznego, który nastąpił dopiero w XVII stuleciu przez króla ${ }^{20}$. Do tej pory realną władzę w mieście sprawował wójt dziedziczny trzymający w swoich rękach władzę sądową (był jednocześnie wójtem sądowym). Po nim władze w mieście przejmowali kolejni dzierżawcy. W Bochni, podobnie jak w innych miastach, których nie wykupiono wójtostwa dziedzicznego (a raczej nim nie wykupiono tegoż wójtostwa) dochodziło do tarć między mieszczaństwem reprezentowanym przez samorząd a wójtem dziedzicznym. Jest to problem szeroko omówiony w literaturze ${ }^{21}$. W dalszych fragmentach nazwijmy to „części teoretycznej” autor pochylił się nad zgromadzeniem 12 mężów, które zapewne można by było nazwać tak zwanym trzecim ordynkiem, mającym jakiś wkład w zarządzanie miastem, często jednak iluzorycznym biorąc pod uwagę działalności kolejnych wójtów dziedzicznych. Na samym końcu omówiono inne urzędy i służby komunalne funkcjonujące w mieście. Treści te potraktowano dość marginalnie, zwłaszcza kancelarię i pisarza na jej czele, którą z pewnością można by opisać lepiej. Ciekawą kwestią pozostaje łączenie urzędu pisarza, ławnika i rajcy ${ }^{22}$. Jest to mało rozpoznane w naszej literaturze i rzadko spotykane w źródłach przynajmniej miast

${ }^{18}$ M. Wyżga, op. cit., s. 18.

${ }_{19}$ M. Bogucka, H Samsonowicz., op. cit., s. 57.

${ }^{20}$ M. Wyżga, op. cit., s. 36.

${ }^{21}$ M. Bogucka, H Samsonowicz., op. cit., s. 479-480 oraz tabela 61; R. Szczygieł, Zabiegi o zmiane ordynacji wyborczej rady miejskiej $w$ Lublinie $w$ ostatnim ćwierćwieczu XV wieku, „Przegląd Zachodniopomorski” 2016, R. 31 (60), z. 1, s. 249-2580; K. Myśliński, Wójt dziedziczny i rada miejska w Lublinie 1317-1504, Lublin 1962, s. 45-61 .

${ }^{22}$ M. Wyżga, op. cit., s. 28. 
szlacheckich Wielkopolski²3. Obok pisarza nieco uwagi poświęcono syndykom, woźnym, stróżom, kalkulatorom, starszym cechowym. Sam autor przyznaje, że nie miał ku temu lepszej sposobności ze względu na ich niewielkie występowanie w źródle.

Przechodząc do samych spisów, w nich również znalazło się parę niedociągnięć, które powinny być wyłapane podczas recenzji wewnętrznej publikacji. Potknięcia te są raczej typowo techniczne niż merytoryczne. Dotyczą one wyrywkowego niepogrubiania określonych dat rocznych, których jednak jest dość dużo ${ }^{24}$. Poza tym niekonsekwencją jest stosowanie w spisach rajców polskich nazw zawodów ${ }^{25}$, a w spisach ławników łacińskich ${ }^{26}$. Można zauważyć, że praktyką autora jest oddawanie nazwisk, wskazujących na zajęcie określoną profesją za pomocą małych liter. Nie wiedzieć dlaczego, autor nie uważa „organisty”, „młynarza”, „chmielarza” oraz „stolarza” za zawód. Skoro zapisał te słowa wielką literą uznał je raczej za przydomek ${ }^{27}$. Na miejscu autora zrezygnowałbym też z podawania w spisach informacji o braku danych. Poza tym, skoro jest to kolejna publikacja w ramach serii, to czy nie warto by było po krótce przybliżyć wytyczne dotyczące spisów?28. Nie ma niczego złego w powielaniu tych samych informacji lecz w innej formie, dzięki temu lepiej się ona rozchodzi i utrwala.

Jak wspomniałem wcześniej, nie ma tu bibliografii załącznikowej. Jednakże po cytowanych publikacjach widać, że autor świetnie orientuje się w literaturze podmiotu dotyczącej miasta Bochni. Natomiast sporym mankamentem jest brak cytowania klasycznej i absolutnie podstawowej pozycji, jaką jest podawana wcześniej przeze mnie publikacja M. Boguckiej i H. Samsonowicza, Dzieje miast i mieszczaństwa w Polsce przedrozbioro$w e j^{29}$ oraz tych odnoszących się do historii miast, ustroju miast. W tej

${ }^{23}$ Znanych autorowi tej recenzji, tj. wszystkich miast szlacheckich Wielkopolski.

${ }^{24}$ M. Wyżga, op. cit., s. 42, 44, 45-47, 52, 111-112, 120, 122, 125-126, 129, 131, 133, 147, 171-172, 175, 194.

25 Ibidem, s. 43-46.

${ }^{26}$ Ibidem, s. 130-131, 138-141, 143-146, 148-149, 151, 153, 156.

${ }^{27}$ Ibidem, s. 72, 137, 147, 182.

28 Ibidem, s. 40.

${ }^{29}$ M. Bogucka, H Samsonowicz, op. cit., passim. 
grupie wymienić należy dorobek naukowy Jana Ptaśnika ${ }^{30}$ (w pracy cytowana jest jedna jego publikacja: Miasta $i$ mieszczaństwo $w$ dawnej Polsce), Ryszarda Szczygła ${ }^{31}$, Henryka Samsonowicza ${ }^{32}$, Antoniego Gąsiorowskiego $^{33}$, Kazimierza Myślińskiego ${ }^{34}$, Stanisława Gierszewskiego ${ }^{35}$, Mieczysława Niwińskiego ${ }^{36}$. Poza tym cenne informacje mogą nieść prace z zakresu archiwistyki, w których czasami podawano informacje o ustroju miasta, wspomnieć tu warto o pracach, Marii Stankowej ${ }^{37}$, Mariana Friedberga ${ }^{38}$, Ireny Radtke ${ }^{39}$, Waldemara Chorążyczewskiego ${ }^{40}$. Brak odwołań w przypisach daje do zrozumienia, iż w czasie pisania tej książki były one autorowi nieznane.

${ }^{30}$ J. Ptaśnik, Spór między radą a pospólstwem na początku XVI w., [w:] Obrazki zprzesztości Krakowa, Kraków 1902; Idem, Studia nad patrycjatem krakowskim, t. I, Kraków 1935; Idem, Studia nad patrycjatem krakowskim wieków średnich, „Rocznik Krakowski” 1913, R. 15, s. 23-96; Idem, Studia nad patrycjatem krakowskim wieków średnich, „Rocznik Krakowski” 1914, R. 16, s. 1-90.

31 R. Szczygieł, Konflikty spoteczne $w$ Lublinie $w$ pierwszej potowie XVI wieku, Warszawa 1977.

${ }^{32}$ H. Samsonowicz, Samorzad miejski $w$ dobie rozdrobnienia feudalnego $w$ Polsce, [w:] Polska w okresie rozdrobnienia feudalnego, red. H. Łowmiański, Wrocław 1973; H. Samsonowicz, $Z$ zagadnień ustrojowych miasta średniowiecznego, [w:] Wieki średnie. Prace ofiarowane T. Manteufflowi, Warszawa 1962; H. Samsonowicz, Zycie miasta średniowiecznego. Warszawa 1970.

33 A. Gąsiorowski, Starostowie wielkopolskich miast królewskich w dobie jagiellońskiej, Warszawa 1981; Idem, Walki o wtadzę w Poznaniu u schytku wieków średnich, „Kwartalnik Historyczny" 1975, R. 82, nr 2, s. 255-266; Idem, Wójt i starosta. Ramię monarsze w polskim mieście średniowiecznym, [w:] Ars historica, Poznań 1976.

${ }^{34}$ K. Myśliński, Wójt dziedziczny i rada miejska $w$ Lublinie 1317-1504, Lublin 1962.

35 S. Gierszewski, Obywatele Polski przedrozbiorowej, Warszawa 1973.

${ }_{36}$ M. Niwiński, Wójtostwo krakowskie w wiekach średnich, Kraków 1938.

${ }^{37}$ M. Stankowa, Kancelaria miasta Lublina XIV-XVIII w. Warszawa 1968.

${ }_{38}$ M. Friedberg, Kancelaria miasta Kazimierza pod Krakowem, „Archeion” 1962, t. 36; Idem, Kancelaria miasta Krakowa do potowy XVIII wieku, „Archeion” 1955, t. 24.

39 I. Radtke, Kancelaria miasta Poznania do roku 1570, Warszawa 1967; Eadem, Kancelaria miasta Poznania od XIII do XV wieku, „Roczniki Historyczne” 1961, t. 27, s. 161-189; Eadem, Kancelaria miasta Poznania w latach 1570-1793, [w:] Historia prawa, historia kultury, red. E. Borkowska-Bagieńska, H. Olszewski, Poznań 1994.

${ }^{40}$ W. Chorążyczewski, op. cit., s. 61-94. 
Prezentacja wyników badań jest indywidualną kwestią każdego autora. Jest to prawo niepodważalne. Pozwala to wybierać lub odrzucać tezy, z którymi się zgadzamy bądź nie. Jednakże odbiorcom/czytelnikom pozostaje wyrażenie krytyki i oceny przydatności do swoich badań. Pomimo wytkniętych mankamentów, prezentowana tu publikacja jest oczywiście pozycją ważną i godną uwagi. Z pewnością każdy badacz zajmujący się kulturą prawno-kancelaryjną w szerokim tych słów znaczeniu będzie zmuszony sięgnąć po tę pracę. Do grona odbiorców doliczyć należy stale rosnącą grupę regionalistów, którzy i dla siebie znajdą cenne informacje. Sporządzanie spisów nie jest zadaniem łatwym, wymaga od autora sporej uwagi i cierpliwości zarazem. Zważywszy na fakt, iż każda nawet niewielka pomyłka będzie trudna do wyśledzenia, a rozpoczęcie pracy od nowa nie wchodzi w rachubę. Zwłaszcza, jeśli pracuje się na tak obszernym materiale źródłowym. Z pewnością ogrom wykonanej przez autora pracy przysłania wzmiankowane tu potknięcia. A marginalne ujęcie wskazanych tu wątków otwiera możliwość pogłębienia badania, chociażby dokładniejszego prześledzenia cursus honorum i oddanie w osobnym artykule. 